\title{
Isolated Splenic Metastasis from Renal Cell Carcinoma: Case Report and Review
}

\author{
J.A.G. Moir $\quad$ G. Sen ${ }^{a} \quad$ R. Saif ${ }^{a} \quad$ B. Haugk ${ }^{b} \quad$ J.J. French ${ }^{a}$ \\ Departments of a Hepatobiliary and Pancreatic Surgery and ${ }^{b}$ Pathology, \\ Freeman Hospital, Newcastle upon Tyne, UK
}

\section{Key Words}

Spleen · Metastasis $\cdot$ Renal cell carcinoma

\begin{abstract}
This report presents the case of a 70-year-old woman with a previous history of a left nephrectomy for renal cell carcinoma (RCC), who developed general malaise and fatigue. Abdominal computed tomography demonstrated an enhancing $6 \times 7 \mathrm{~cm}$ necrotic lesion in the lower pole of the spleen suggestive of a metastasis. Given the highly suspicious nature of the lesion we proceeded to splenectomy. The tumour did not breach the splenic capsule, and there was no local diaphragmatic involvement. The mass was concluded to be a true metastasis of the original RCC rather than local recurrence of the disease. The causes of isolated solid splenic lesions are wide and varied, however a past or present history of malignancy should lead to a high index of suspicion for a splenic metastasis. We report an extremely unusual case of spread from a RCC.
\end{abstract}

\section{Introduction}

Metastasis to the spleen is infrequent but varies greatly from series to series (1.6 to $30 \%$ ), depending on the thoroughness of examination and selection of cases [1]. The most common primaries are lung cancer, cutaneous malignant melanoma, and breast cancer [2]. Splenic metastasis generally indicates late dissemination of disease, and it is unusual to find isolated splenic lesions from solid organ malignancies, with fewer than 25 cases reported worldwide [3]. Spread from renal cell carcinoma (RCC) is extremely unusual. We report the case of a woman who presented with a splenic lesion 11 months after radical nephrectomy. 


\begin{tabular}{c|l|l|l}
$\begin{array}{r}\text { Case Reports in } \\
\text { Gastroenterology }\end{array}$ & $\begin{array}{l}\text { Case Rep Gastroenterol 2011;5:166-171 } \\
\text { DOI: 10.1159/000326963 }\end{array}$ & $\begin{array}{l}\text { Published online: } \\
\text { April 12, 2011 }\end{array}$ & $\begin{array}{l}\text { O 2011 S. Karger AG, Basel } \\
\text { ISSN 1662-0631 } \\
\text { www.karger.com/crg }\end{array}$ \\
\hline
\end{tabular}

\section{Case Report}

A 70-year-old Caucasian female presented with a 4-week history of malaise and fatigue. She had undergone a left radical nephrectomy for RCC 11 months earlier. This renal tumour had been incidentally discovered on a follow-up abdominal CT scan she was having following a total abdominal hysterectomy and adjuvant radiotherapy for stage 1c endometrial carcinoma 4 years prior.

Histological examination of the renal mass had shown a tumour of conventional clear cell type. There was some invasion of the tumour into the perinephric fat and a segmental branch of left renal vein (stage pT3b). Small deposits of tumours were noted on the surface of the fat resection margin. In light of this and the associated increased risk of recurrence, she received a follow-up un-enhanced CT 6 months post-operatively which showed no recurrence, and was due further urological follow-up prior to her new presentation to the general practitioner 11 months post-nephrectomy with lethargy.

At this time she was found to be anaemic (haemoglobin $10.4 \mathrm{~g} / \mathrm{dl}$ ) and had a raised alkaline phosphatase level of $188 \mathrm{IU} / \mathrm{l}$ (the remainder of liver function tests were normal). A CT scan revealed an enhancing $6 \times 7 \mathrm{~cm}$ necrotic lesion in the lower pole of the spleen, thought to be a metastasis from her previous RCC, with her previous endometrial carcinoma being a less likely primary. It was uncertain whether this was indeed a true metastasis or a local recurrence of her previous left renal tumour. There was no evidence of any other metastatic disease on cross-sectional imaging of the chest and abdomen. After discussion in a multidisciplinary setting, although an uncommon event, the splenic lesion was thought likely to be an isolated splenic metastasis from her previous RCC and resection was recommended. Laparoscopic biopsy was not thought to be helpful in this case. The patient was carefully counselled and her fitness for resectional surgery assessed. She elected to undergo surgery (open splenectomy), had an uncomplicated procedure/recovery and was discharged from hospital on the eighth post-operative day.

The removed spleen weighed $450 \mathrm{~g}$ and measured $120 \times 105 \times 70 \mathrm{~mm}$. Serial slicing revealed a circumscribed centrally necrotic cream-coloured tumour measuring $90 \times 63 \times 55 \mathrm{~mm}$ (fig. 1 ). In addition, two fragments of diaphragmatic tissue were sampled to assess for any evidence of tumour spread.

Histological examination of the splenic lesion showed a well-circumscribed, partly encapsulated tumour of solid islands and sheets of cells with an abundant amount of predominantly clear but also eosinophilic cytoplasm (fig. 2). Widespread necrotic foci were noted. The tumour was found to bulge into the splenic capsule but no definite evidence of capsular breach was found. There was also no evidence of vascular invasion and the lesion was clear of the splenic hilum.

No evidence of disease was found in histological samples taken from the diaphragm and therefore the mass was concluded to be a true metastasis of the original RCC rather than local recurrence of the disease. The patient has received on-going follow-up under the care of the urology team, with 6-monthly CT scans which have thus far not shown any evidence of disease recurrence 24 months post-splenectomy.

\section{Discussion}

The causes of isolated solid splenic lesions are wide and varied, and as such can present a diagnostic challenge. A splenic mass without any history of malignancy suggests a primary lesion such as lymphoma, vascular tumours or infectious lesions. Any past or present history of malignancy however would lead to a high index of suspicion for a splenic metastasis [4]. In the presence of isolated splenic metastasis, it must always be considered that there is an undiagnosed primary lesion. Interestingly this has been described by McGregor et al. who reported a clinically unidentified RCC diagnosed by fine needle aspiration of the spleen [5]. Further differential diagnoses for isolated splenic mass include rarer lesions such as hamartoma and inflammatory pseudotumour, which 
can both clinically and radiologically mimic a metastatic tumour [4]. One should also consider the possibility of secondary involvement of the spleen through direct invasion, for example from a RCC [6].

Splenic metastases were previously considered exceptionally rare, however more recent advances in radiological imaging and the increased follow-up of patients with cancer means that the rate of detection has increased [7]. Splenic metastases are often asymptomatic. An autopsy study found only $8 \%$ of 92 patients with secondary non-lymphoid splenic lesions at autopsy were symptomatic. These symptoms included an enlarging abdominal mass or abdominal pain [8].

The majority of splenic metastases are part of a multi-visceral metastatic disease, and the detection is often made soon after diagnosis of the primary tumour (mean duration after detection of primary tumour is 6.7 months), however this is often late in the course of disseminated disease [8]. There has however been a case of splenic metastasis 5 years after a radical prostatectomy for prostate carcinoma [9]. This case, along with recent advances in the knowledge of the metastatic process, makes it seem likely that late occurrence of solitary splenic metastases might develop from early blood-borne micrometastasis within the spleen after a period of clinical latency [4].

In an autopsy study of splenic metastasis, the rate of dissemination to the spleen was highest from lung cancer, cutaneous malignant melanoma, and breast cancer, accounting for $24.6,15.8$, and $12.3 \%$ of all spleen metastases, respectively [2]. RCC has been reported to have spread to nearly every organ; however the incidence of splenic metastasis is relatively low, with a $4.6 \%$ incidence in an autopsy study [10].

To our knowledge there have been only 8 cases of a splenic metastasis from a RCC that presented clinically and has been reported on, including our study [11-17]. The incidence of isolated splenic metastasis from any given primary is also particularly rare, with only $5.3 \%$ being found to be isolated at autopsy [8].

The reason for the relative rarity of splenic metastases might be explained by two main causes: (1) mechanical factors impeding the splenic implantation of blood-borne cancer cells, such as the constant flow of blood through the spleen and the rhythmic contraction of the splenic capsule, the sharp angle of the splenic artery branching from the coeliac trunk thus preventing large clumps of tumour cells from passing through, and the lack of afferent lymphatic vessels limiting lymphogenic metastases, and (2) the inhibitory effect of the splenic microenvironment on the growth of metastatic cells [18].

Advances in imaging techniques have not only resulted in an increase in the detection of splenic lesions, but also in the cellular diagnosis using percutaneous biopsy (using ultrasound or CT guidance) [7, 19] or endoscopic fine needle aspiration [20].

Given that a splenic metastasis is often found in the context of disseminated malignancy, it tends to have no clinical importance. A splenectomy however can be indicated for palliative symptomatic relief, with reports of acceptable morbidity and improvements in quality of life [21]. 


\begin{tabular}{c|l|l|l}
$\begin{array}{r}\text { Case Reports in } \\
\text { Gastroenterology }\end{array}$ & $\begin{array}{l}\text { Case Rep Gastroenterol 2011;5:166-171 } \\
\text { DOI: 10.1159/000326963 }\end{array}$ & $\begin{array}{l}\text { Published online: } \\
\text { April 12, 2011 }\end{array}$ & $\begin{array}{l}\text { O 2011 S. Karger AG, Basel } \\
\text { ISSN 1662-0631 } \\
\text { www.karger.com/crg }\end{array}$ \\
\hline
\end{tabular}

\section{Conclusion}

The incidence of a solitary splenic metastasis from a RCC is particularly rare. They are often asymptomatic and picked up either incidentally or on surveillance imaging for previous malignancy. A splenectomy is an effective and safe option for symptomatic relief and prevention of future complications.

\section{Disclosure Statement}

No conflict of interest declared.

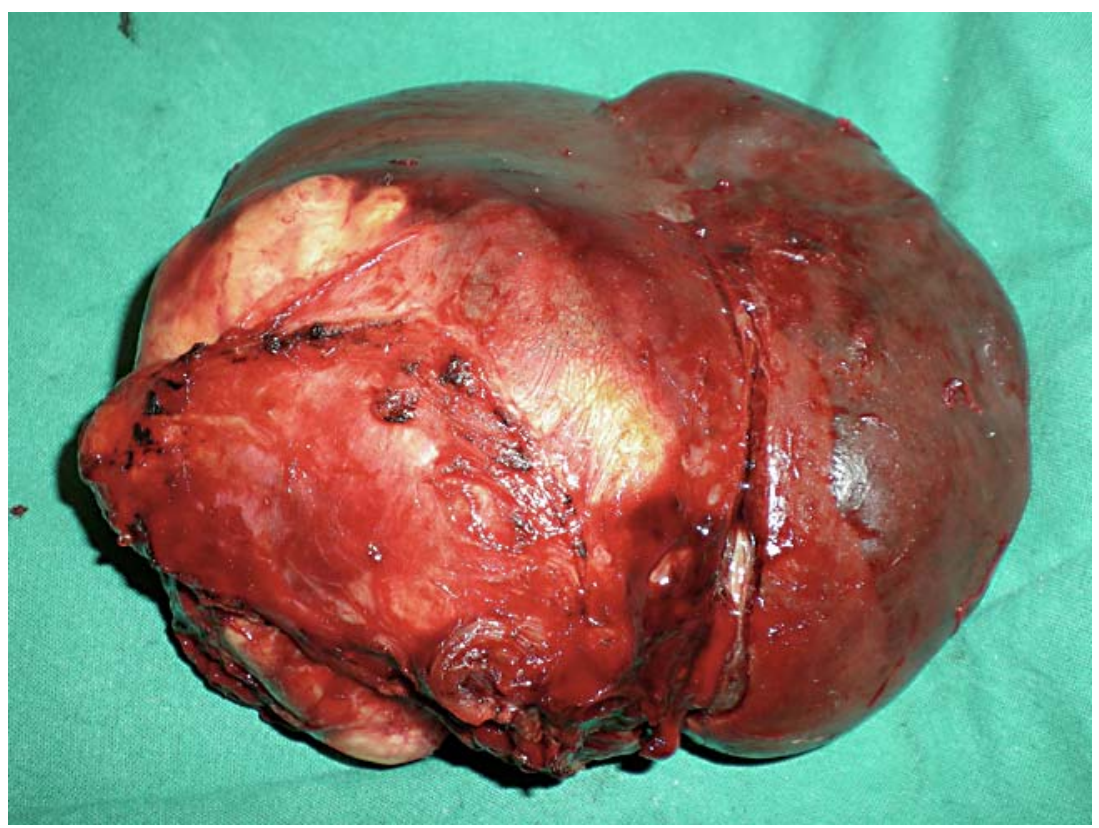

Fig. 1. Macroscopic appearance of removed spleen containing tumour. 


\begin{tabular}{c|l|l|l}
$\begin{array}{r}\text { Case Reports in } \\
\text { Gastroenterology }\end{array}$ & $\begin{array}{l}\text { Case Rep Gastroenterol 2011;5:166-171 } \\
\text { DOI: 10.1159/000326963 }\end{array}$ & $\begin{array}{l}\text { Published online: } \\
\text { April 12, 2011 }\end{array}$ & $\begin{array}{l}\text { O 2011 S. Karger AG, Basel } \\
\text { ISSN 1662-0631 } \\
\text { www.karger.com/crg }\end{array}$ \\
\hline
\end{tabular}

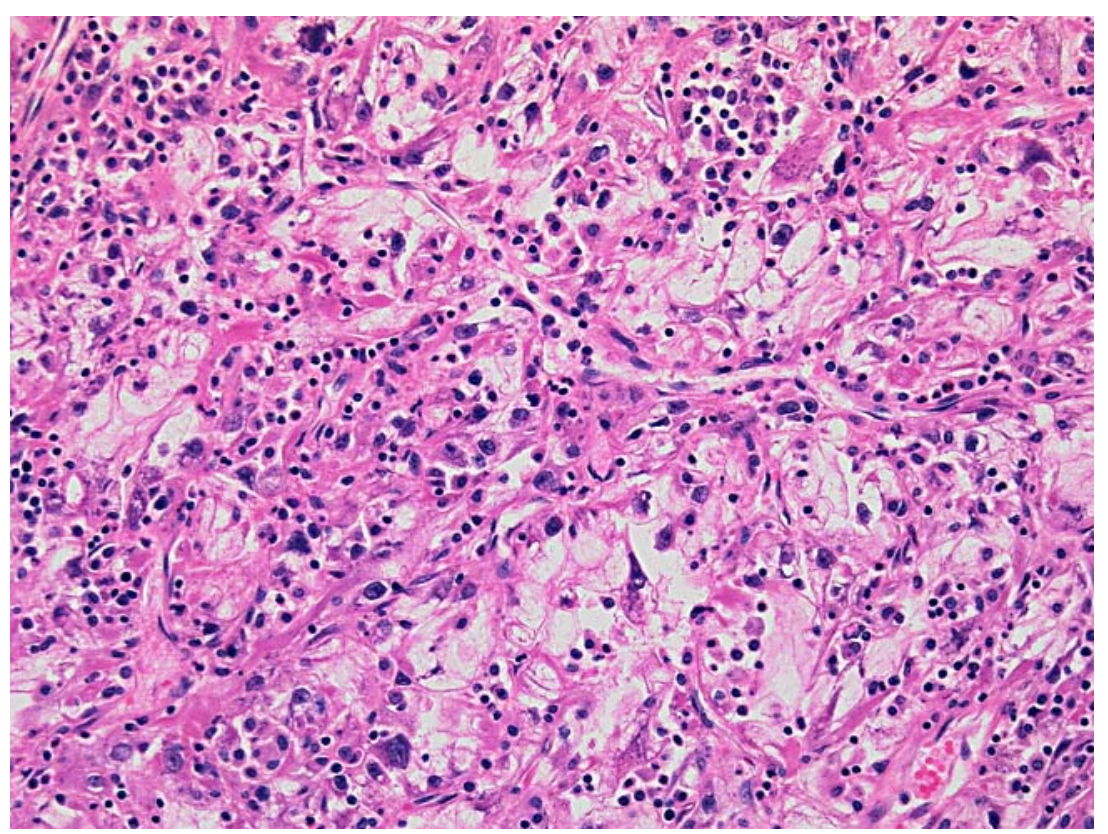

Fig. 2. Histology from splenic metastasis showing tumour cells with both clear and eosinophilic cytoplasm. The cells have moderately pleomorphic nuclei, some with very prominent nucleoli. Focally multilobulated nuclei are also seen.

\section{References}

1 Warnke RA, Weiss LM, Chan JKC, Cleary ML, Dorfman RF: Tumors of the lymph nodes and spleen. In: Atlas of Tumor Pathology, third series, fascicle 14. Washington DC, Armed Forces Institute of Pathology, 1995, pp 508-509.

2 Schön CA, Görg C, Ramaswamy A, Barth PJ: Splenic metastases in a large unselected autopsy series. Pathol Res Pract 2006;202:351-356.

3 Koh YS, Kim JC, Cho CK: Splenectomy for solitary splenic metastasis of ovarian cancer. BMC Cancer 2004;4:96.

4 Compérat E, Bardier-Dupas A, Camparo P, Capron F, Charlotte F: Splenic metastases: clinicopathologic presentation, differential diagnosis, and pathogenesis. Arch Pathol Lab Med 2007;131:965-969.

-5 McGregor HD, Wu Y, Weston AP, McAnaw MP, Bromfield C, Bhattatiry MM: Metastatic renal cell carcinoma of spleen diagnosed by fine-needle aspiration. Am J Med Sci 2003;326:51-54.

-6 Suzuki M, Machida T, Masuda F, Yanagisawa M, Tashiro K, Onishi T, Kishimoto K, Suzuki M, Ishikawa E: A case of renal cell carcinoma invading spleen. Nippon Hinyokika Gakkai Zasshi 1982;73:1333-1337.

7 Metser U, Miller E, Kessler A, Lerman H, Lievshitz G, Oren R: Solid splenic masses: evaluation with 18F-FDG ET/CT. J Nucl Med 2005;46:52-59.

8 Lam KY, Tang V: Metastatic tumors to the spleen. A 25-year clinicopathologic study. Arch Pathol Lab Med 2000;124:526-530.

-9 Compérat E, Azzouzi A, Chartier-Kastler E, Ménégaux F, Capron F, Richard F, Charlotte F: Late recurrence of a prostatic adenocarcinoma as a solitary splenic metastasis. Urol Int 2007;78:86-88.

10 Bennington JL, Beckwith JB: Tumors of the Kidney, Renal Pelvis and Ureter. Atlas of Tumor Pathology, second series, fascicle 12. Washington DC, Armed Forces Institute of Pathology, 1975, pp 168-174.

-11 Strum WB. Remote recurrence of renal cell carcinoma. Urology 1984;23:68-70.

12 Murao Y, Kakiuchi T, Nakahashi H, Ashihara T: A case of renal cell carcinoma metastasized to the spleen after 10 years of nephrectomy (in Japanese). Naika 1987;59:582-584.

$\checkmark 13$ Pal KK, Guha D, Banerjee D: Early splenic metastasis in a case of renal adenocarcinoma. J Indian Med Assoc 1995;93:276-277. 


\begin{tabular}{c|l|l|l}
$\begin{array}{r}\text { Case Reports in } \\
\text { Gastroenterology }\end{array}$ & $\begin{array}{l}\text { Case Rep Gastroenterol 2011;5:166-171 } \\
\text { DOI: 10.1159/000326963 }\end{array}$ & $\begin{array}{l}\text { Published online: } \\
\text { April 12, 2011 }\end{array}$ & $\begin{array}{l}\text { O 2011 S. Karger AG, Basel } \\
\text { ISSN 1662-0631 } \\
\text { www.karger.com/crg }\end{array}$ \\
\hline
\end{tabular}

14 Suzuki T, Sugaya K, Ogura Y, Shimoda N, Miyagata S, Nishizawa O, Katou T: A case of spleen metastasis of renal cell carcinoma (in Japanese). Hinyokigeka 1996;9:1079-1081.

15 Tatsuta M, Shiozaki K, Masutani S, Hashimoto K, Imamura H, Ikeda M, Miya A, Ishida H, Kawasaki T, Furukawa H, Satomi T, Hoshida Y: Splenic and pulmonary metastases from renal cell carcinoma: report of a case. Surg Today 2001;31:463-465.

16 Ielpo B, Mazzetti C, Venditti D, Buonomo O, Petrella G: A case of metachronous splenic metastasis from renal cell carcinoma after 14 years. Int J Surg 2010;8:353-355.

-17 Kugel V, Dekel Y, Konichezky M, Baniel J, Livne PM, Koren R: Unusual splenic metastasis from renal cell carcinoma. A case report and review of the literature. Pathol Res Pract 2003;199:739-743.

18 Compérat E, Charlotte F: Splenic metastases: diagnostic methods; in Hayat MA (ed): Method of Cancer Diagnosis, Therapy, and Prognosis - Liver Cancer. Union, NJ, Springer, 2009, vol. 5, pp 489-497.

19 Caraway NP, Fanning CV: Use of fine-needle aspiration biopsy in the evaluation of splenic lesions in a cancer center. Diagn Cytopathol 1997;16:312-316.

20 Fritscher-Ravens A, Mylonaki M, Pantes A, Topalidis T, Thonke F, Swain P: Endoscopic ultrasound-guided biopsy for the diagnosis of focal lesions of the spleen. Am J Gastroenterol 2003;98:1022-1027.

21 De Wilt JH, McCarthy WH, Thompson JF: Surgical treatment of splenic metastases in patients with melanoma. J Am Coll Surg 2003;197:38-43. 